\title{
REDACTIONEEL
}

\section{Crimmigratie: What's in a word?}

\author{
Maartje van der Woude
}

In een tijd van oneliners, buzzwords en fake news, zeker waar het vraagstukken op het terrein van veiligheid en migratie betreft, is het van groot belang om stil te staan bij de kracht van taal en de mogelijke impact van woorden. Immers, taal beïnvloedt gedachten en acties. De woorden die we gebruiken om objecten maar ook om gebeurtenissen of fenomenen te omschrijven - aan onszelf maar ook aan anderen - beïnvloeden hoe wij en hoe anderen denken en handelen. Als redactie van een blad dat in de titel een niet alledaagse term in zich draagt, 'crimmigratie', voelen wij dan ook een bijzondere verantwoordelijkheid om goed inzicht te bieden in wat we wel, en ook wat we juist helemaal niet, onder deze term verstaan. Voor mij is de schone taak weggelegd om, aansluitend bij de (inter)nationale literatuur, deze begripsbepaling in kaart te brengen.

\section{Een Amerikaanse uitvinding}

Het strafrecht en het immigratierecht zijn verschillende, duidelijk van elkaar gescheiden, rechtsgebieden, beide met eigen uitgangspunten en waarborgen. Desalniettemin hebben verschillende juristen in binnen- en buitenland geobserveerd dat deze strikte scheiding tussen beide rechtsdomeinen langzaamaan begon te vervagen en dat het strafrecht trekken van het immigratierecht begon aan te nemen en andersom. Amerikaanse professor Juliet Stumpf was een van deze juristen en zij verbond aan dit fenomeen het begrip 'crimmigratie'. Het begrip als dusdanig beoogde dus een fenomeen te beschrijven dat door andere Amerikaanse rechtsgeleerden, waaronder Steven Legomsky, Daniel Kanstroom, Teresa Miller en Michael Welch, reeds geruime tijd werd bestudeerd. ${ }^{1}$ Tijdens een kleine conferentie in 2006, aan de State University of New York in Buffalo, introduceerde Stumpf het begrip in haar - toen nog niet gepubliceerde - paper 'Crimmigration

1 T.A. Miller, 2003. 'Citizenship \& Severity: Recent Immigration Reforms and the New Penology', Georgetown Immigration Law Journal 2003, 17:611-66; T.A. Miller, 'Blurring the boundaries between immigration and crime control after September 11th', Boston College Third World Law Review 2005, 25, p. 81-123; D. Kanstroom, 'Deportation, Social Control, and Punishment: Some Thoughts About Why Hard Laws Make Bad Cases', Boston College Law School Journal 2000, 113:1890-1935; D. Kanstroom,'Criminalizing the Undocumented: Ironic Boundaries of the PostSeptember 11th "Pale of Law", Boston College Law School Journal 2004, 29:639-70; S.H. Legomsky, 'The New Path of Immigration Law: Asymmetric Incorporation of Criminal Justice Norms', Washington \& Lee Law Review 2007, 64:469-528; M. Welch, 'The Sonics of Crimmigration in Australia: Wall of Noise and Quiet Manoeuvring', The British Journal of Criminology 2012, Volume 52, Issue 2, 324-344. 
Crisis'. ${ }^{2}$ Als tweedejaars $\mathrm{PhD}$-student had ik het bijzondere genoegen om in het illustere gezelschap van al deze crimmigration-scholars te mogen verkeren om met hen onder meer te bespreken hoe in de context van de Nederlandse antiterrorisme-aanpakdiscussies ook een dergelijke vervaging tussen beide rechtsdomeinen zichtbaar was. ${ }^{3}$ Ik herinner me nog de discussies en de opmerking van Juliet dat ze 'just playing around' was met het begrip. Een jaar later, toen haar artikel was gepubliceerd in de American University Law Review bleek dat ze met het introduceren van begrip 'crimmigration' en haar analyse daarvan door de lens van 'membership theory' tot de verbeelding van veel juristen, maar later ook sociaalwetenschappers zou spreken. Volgens de 'membership theory' kunnen slechts zij die als volwaardig lid van de samenleving worden aangemerkt, en dus vallen onder het sociaal contract tussen de overheid en de samenleving, aanspraak maken op individuele rechten en privileges. De overheid kan individuen tijdelijk of permanent dit lidmaatschap van de gemeenschap, van de samenleving, ontzeggen en hen buitensluiten. Zowel het strafrecht als het immigratierecht bieden de overheid daartoe de nodige middelen. Het begrip crimmigratie bleek in haar eenvoud aldus een veelheid aan processen te omvatten waar velen zich zorgen om maakten. Het begrip werd, zeker in de Amerikaanse context, in toenemende mate door - in het bijzonder - juristen gebruikt. Wanneer we kijken naar Nederland, dan zien we echter dat hoogleraar criminologie Joanne van der Leun in 2010 het begrip voor het eerst in het Nederlands introduceerde in haar gelijkluidende oratie. $^{4}$

\section{De drie pijlers van crimmigratierecht}

Wat ik voor het gemak maar even de 'eerste generatie' crimmigratieliteratuur noem, analyseerde het vervlochten raken van strafrechtelijke en immigratierechtelijke normen. Waar dit in eerste instantie, en nu nog steeds in groten getale, met name door Amerikaanse rechtsgeleerden en praktijkjuristen werd bestudeerd en beschreven, laat de weelderig bloeiende crimmigratieliteratuur inmiddels geen enkele illusie dat deze vervlechting niet ook op grote schaal in andere landen zichtbaar is. ${ }^{5}$ In de hoedanigheid van juridisch fenomeen kan het begrip crimmigratierecht (in het Engels heeft men het doorgaans over crimmigration law) duiden op drie verschillende ontwikkelingen: in de eerste plaats op een toename in het aantal strafbare feiten dat kan leiden tot immigratierechtelijke consequenties, in het bijzonder verwijdering. In de tweede plaats kan crimmigratie duiden op de criminalisering van immigratierechtelijke omstandigheden. Hierbij kan gedacht worden aan - terugkerende - discussies over de strafbaarstelling van illegaal ver-

2 J. Stumpf, 'The crimmigration crisis: Immigrants, crime, and sovereign power', American University Law Review 2006, p. 367-419.

3 Het betrof de conferentie 'Merging Immigration and Crime Control' aan de State University of New York in Buffalo op 27-28 april, 2006.

4 J.P. van der Leun, Crimmigratie, Apeldoorn/Antwerpen: Maklu-Uitgevers 2010.

5 Zoals ook uit onze vaste rubriek 'Literatuur' blijkt, wordt er inmiddels door onderzoekers vanuit een veelheid aan landen onderzoek gedaan naar het begrip, en het proces van, crimmigratie. 
blijf. Het strafrecht is op deze manier een middel om irregulier verblijf af te straffen en, middels afschrikking, te voorkomen. Tot slot verwijst het begrip ook naar de zichtbare parallellen in de uitvoeringspraktijk, waarbij er voor wat betreft het vinden van manieren en strategieën om immigratie te beheersen in toenemende mate inspiratie lijkt te worden geput uit strategieën en praktijken zoals gebruikt binnen de context van strafrechtelijke handhaving en detentie.

\section{Van juridisch naar interdisciplinair concept}

Door de jaren heen is het palet aan onderzoekers dat zich met het concept crimmigratie bezig ging houden meer divers geworden. Niet alleen in termen van geografische herkomst, maar in het bijzonder ook in disciplinaire achtergrond. Crimmigratie ontwikkelde zich, los van in de rechtswetenschap, al snel als een specifieke onderzoeklijn binnen onder meer de sociologie, de criminologie en de politicologie. Dit heeft tot gevolg gehad dat er meer aandacht is gekomen voor het ook op empirische wijze bestuderen van de drie in de vorige paragraaf uiteengezette klassieke 'pijlers' waar crimmigratie op berust. Ook het vinden van verklaringen voor crimmigratie, het vinden van de drijvende krachten achter dit fenomeen, heeft in de 'tweede generatie' crimmigratieliteratuur meer aandacht gekregen. Omdat het recht, en juridische procedures, niet los kunnen worden gezien van de politiek-maatschappelijke context waarbinnen zij tot stand komt en haar doorwerking vindt, is het bestuderen van het maatschappelijk en politiek discours inmiddels ook van groot belang: hoe praten burgers en politici over criminaliteit en migratie, wat of wie zien zij als gevaar en waarom? Niet alleen de percepties en opvattingen van burgers en politici doen ertoe, maar ook de opvattingen, inschattingen en afwegingen van hen die werkzaam zijn binnen de immigratie- of strafrechtsketen. Het zijn juist de beslissingen van individuele ambtenaren die ertoe doen. ${ }^{6}$ De Noorse criminoloog en rechtssocioloog Katja Franko introduceert in 2011 dan ook de definitie dat crimmigratie niet zozeer ziet op de vervlechting van het strafrecht en het immigratierecht maar op het vervagen van de grenzen tussen het management en de controle van criminaliteit en veiligheid aan de ene kant en het management en de controle van migratie aan de andere kant. ${ }^{7}$ Door het op deze manier openbreken van de definitie van crimmigratie ontstond er meer ruimte om voor wat betreft het op empirische wijze bestuderen van het fenomeen aan te sluiten bij sociale theorievorming over machtsuitoefening en sociale controle door statelijke en, in toenemende mate, ook niet-statelijke, private, actoren.

6 Zie bijvoorbeeld over de rol van discretionaire beslisruimte en crimmigratie: M.A.H. van der Woude, Chain Reactions in Criminal Justice. Discretion and the Necessity of Interdisciplinary Research, Den Haag: Eleven International Publishers 2016.

7 K. Franko, 'Crimmigrant Bodies and Bona Fide Travelers: Surveillance, Citizenship and Governance', Theoretical Criminology 2011, 15 (3): 331-46. Zie ook: J.P. van der Leun \& M.A.H. van der Woude, 'A Reflection on Crimmigration in the Netherlands: On the Cultural Security Complex and the Impact of Framing', in: M.J. Guia, M.A.H. van der Woude \& J.P. van der Leun (ed.), Social Control and Justice: Crimmigration in the Age of Fear, Den Haag: Eleven International Publishing 2013, p. 41-60; M.A.H. van der Woude, J.P. van der Leun \& J.-A.A. Nijland, 'Crimmigration in the Netherlands', Law Soc Inq 2014, 39: 560-579. 
Hoewel onderzoekers, afhankelijk van hun discipline, de crimmigratietrend op verschillende wijzen benaderen en verklaren, constateren zij allemaal dat op deze manier - door middel van juridische middelen en maatregelen - een alsmaar toenemende populatie outsiders wordt gecreëerd. Er is sprake van een (on)bewuste marginalisering van vreemdelingen die hen in een hoek drijft waar er - op dit moment - doorgaans sprake is van een rechtsbeschermingsvacuüm. Met als doel om juist dit onwenselijke gevolg en de mate waarin we het proces van crimmigratie in Nederland en Europa ook steeds verder vorm zien krijgen, inzichtelijker te maken en ter discussie te stellen middels zowel juridische als sociaalwetenschappelijke inzichten, is het u voorliggende tijdschrift in het leven geroepen.

\section{Ter afsluiting}

$\mathrm{Nu}$ uiteengezet is wat er wel en niet onder het begrip crimmigratie gevat moet worden wat ons als redactie betreft, is het van belang om even terug te komen bij de zinspeling op het huidige politiek klimaat waar ik dit redactioneel mee begon. Het is namelijk naïef om niet ook stil te staan bij de mogelijk, bewust dan wel onbewust, verkeerde uitleg van de term waarbij men onder crimmigratie het tegenovergestelde verstaat van wat we hiervoor hebben betoogd: niet zozeer het door wetgeving, beleid en tenuitvoerlegging verwikkeld raken van vreemdelingentoezicht en criminaliteitsbeleid, maar het plegen van criminaliteit door immigranten. Dit mogelijke misbruik van de term maakt dat er zowel in binnen- en buitenland ook geluiden opgaan om de term niet te gebruiken. ${ }^{8}$ Als redactie zijn we ons bewust van deze geluiden. We hopen desalniettemin dat we door duidelijk gemaakt te hebben hoe wij het begrip in de context van het tijdschrift uitleggen en definiëren, hebben weten te overtuigen van de kracht van het concept en onze bedoeling om juist de problematische aspecten van de vervlechting van vreemdelingentoezicht en criminaliteitsbeleid, de vervlechting van immigratierecht en strafrecht, voor het voetlicht te brengen.

8 Tijdens het tweejaarlijks congres van het Crimmigration Control International Net of Studies (CINETS) in Maryland in 2016 werd ook aan deze kwestie, onder meer door Juliet Stumpf, aandacht besteed. 